\title{
Some Reasons of Using Native Language as Medium of Instruction at Non-English Department
}

\author{
Sri Sukarni ${ }^{1}$,Tri Setianingsih ${ }^{2}$, Terasne $^{3}$ \\ ${ }^{1}$ srisukarni63@gmail.com, ${ }^{2}$ trisetianingsih@ikipmataram.ac.id, ${ }^{3}$ terasne@ikipmataram.ac.id \\ ${ }^{1,2,3}$ Mandalika University of Education
}

\begin{abstract}
This research aimed to describe the reasons for using the Indonesian language as a medium of instruction at non-English department students. This research is conducted at non English department of Mandalika University of Education and there were two English general lecturers and 14 students taken as samples. Type of research used in this research was descriptive quantitative research by survey model. Data were taken from the result of questionnaires answered by both lecturers and students then analyzed by using frequency and percentage. Based on the research findings it can be concluded that there were ten reasons of using Indonesian as medium of instruction for non-English department students. Those ten reasons covered three functions that for teaching language skills, teaching the component of language skills and class management. The three functions gave positive effect in teaching and learning English at non-English department. For teaching language skills aimed to develop students' understanding in reading comprehension, to discuss among students is easier, and to make English easy to learn. The using of Indonesian in component of language skills aimed to explain difficult words in reading text in students' native language, to explain grammar, to explain error made by the students. The reasons of using Indonesian in classroom management can be seen before and after teaching and learning process such as to explain new English teaching material, to develop learning atmosphere more comfortable, to ensure understanding of previous teaching material and giving instruction for assignment or test.
\end{abstract}

Keywords: some reasons, native language, medium of instruction, non-English

\section{INTRODUCTION}

It often becomes a point of discussion for English teachers in teaching and learning English what is the right balance between using English and native language in English classroom. In one side they agree that the more English is applied in, the quicker the students study English. Teaching English by native language can help students in understanding the foreign language. In another side argument has also arisen to justify the using of students' native language in certain situation. In another sentence it has often been said that teacher should use English when possible and students' native language when necessary.

For many years, the teaching English as a foreign language has tended to change its course from what is generally called grammatical oriented became communicative oriented. The reason behind this shift is that the goal of foreign language teaching and learning is to prepare the learners to be able to use foreign language in real communication. In foreign language 
teaching situation, teachers have been encouraged to use communicative teaching approaches and minimize the use of traditional methods such as Grammar Translation Method.

In addition to socio cultural, the native language of the learners plays a major role in learning the second language. (Joukoulian, 2016). In the traditional teacher approach the learners' native language is used to understand the target language. The activity in teaching using Grammar Translation Method is a combination of learning grammar and translation. When teaching grammar, for example teachers try to explain it using native language due to the sentence structure of Indonesian is different from that of English. Students understand the sentences easily because target language is translated into their mother tongue.

Each language teaching method claims that the objective of language teaching is to use the language. It is difficult to find approach that avoids the use of language being learnt (Nunan, 1989). However, teachers faced reality in English classroom that learning English is not an easy matter for students. David Atkinson (1993) assumes that learning a language is difficult and often frustrating process for many leaners, particularly at lower level. He also argued that it is not difficult to think of several general advantages of judicious use of the mother tongue, suggesting that such activities as grammar explanation, checking comprehension, giving instruction, discussion classroom methodology and checking for sense feel into this category (Atkinson, 1987). If teachers can use students' language, he claims these tasks will be expedited more efficiently.

Why do students use their native language in class? According to Harmer (2001)the students use their native language in the classroom is because it is entirely natural thing to do as well if teachers frequently use the students' language, then the students feel comfortable to do it too. Another reason is that translation is a natural thing to do in learning a language and code switching between native language and foreign language is regarded as naturally development. The use of mother tongue can sometimes be useful if it is used in due time. (Ostovar\&Norouzi, 2015). It implies that teachers and students are requiredto have consideration in using first language in English classroom.

In the university level, English is not only studied for English major students but also non-English department. In non-English department reading skill is more emphasized than other language skills so that the objective of teaching in order that students can comprehend English textbooks. Next, background of students' such as competence in English can be one of several factors in understanding English texts, so that the use of native language cannot be avoided. 
Previous researches have reported the usage of native language in EFL classrooms. Prodromou in 2002 did the research toward 300 Greek students at three levels, beginner, intermediate, and advanced. He concluded that students seem skeptical about the use of L1 in the classroom, particularly at high levels. Lower level more tendencies to use L1 while high level less accepting L1 in classroom. However the bilingual teachers are in a position to enrich the process of learning by using a mother tongue as a resource or using mother tongue as a bridge towards English.

Rodriguez and Oxbrow (2008) investigated the students' belief of whether the use of the L1 in English (L2) classroom is a facilitator or an obstacle to language learning. Their study found that most of the students said that the use of L1 (Spanish) through translation in the EFL classroom actually helped them improve their L2. The students also appreciated the teachers' translation of English vocabulary and grammar into Spanish.

Mara Salmona (2014) conducted a research at an international bilingual school in Bogota, the research demonstrated the importance of developing the first language in the second language classroom. The mother tongue could be used as support for the second language acquisition process, which makes the learning process easier for students and teachers. The finding of the research was done by Ahmad et al., (2018) displayed that the use of native language by both teachers and students in EFL classroom was an unavoidable phenomenon. Teachers and students responded positively toward the use of L1, maintaining that judicious and balanced use of L1 by teachers and students could be helpful in the EFL teaching and learning process. The result of these studies indicated that L1 use is accepted by most students and supported by teachers. Teachers supported the functional use of L1 and the use of L1 promoted the classroom interaction. There are some factors that should be taken into account when a teacher should decide the use of L1 in L2 classroom (SusanConnik-Hirtz, 2001) as follows: (1). What is the learners' first language?; (2). What is the learners' age; (3). Are we teaching beginners of advanced levels?; (4). What is the ration of students/teaching time per one class; (5). How long is the learner going to study the second language?; (6). What are his/her learning purposes?; (7). Is it one nationality or mixed nationality group?; (8). What is the institution pedagogical policy?; (9). What kind of educational background does the learners have?; (10). In what kind of social context is the teaching of L2 taking place?

To compare the result of the studies above, on the other side L1 is not suggested to be used in English class, because it can interfere the process of mastering the target language (Krashen, 1982; Ellis, 1985). The overuse of L1 can restrict students' exposure to the target 
language (Harmer, 2001). If native language is dominantly used by teachers and students in English class, the target language exposure may be limited. According to Swain (2008), it is a good idea to give the chance to the students to use most L2 in second language classroom to have good written and spoken input. In other words, students need to use English in order to practice to build their language proficiency. In line with previous research, Christina Georgiana(2012), there are some disadvantages when using L1 in L2 classroom. First, the overuse of L1 might become a habit both for teachers and learners in foreign language teaching and learning. If the lectures always rely on the use of L1 it is possible if the use of L1 would be the habit in the classroom. Second, L1 may lead to misunderstanding when the learners try to get their target language. It happened because there are some words in target language do not have the appropriate meaning in the first language or vice versa. Third, when the lectures use L1 to teach foreign language, it may cause negative transfer to the target language. For certain cases, the form of their native language with their foreign language is different, so the negative transfer may happen more often.

This problem needs lectures to be flexible in using the language when they are teaching the students in English classroom. For example, the use of Indonesian only be use when explain certain subjects such as grammar and vocabulary, while the use of English can be applied when teaching pronunciation. Although many researchers believe that teaching by using English give better result to students' improvement in English language learning, research on Indonesian students need to be investigated further. The goal of this research then is to investigate learners' perception in teaching English using Indonesian and English, students' preference for language use in classroom as the medium of instruction, and reasons of using L1 and class. find evidence to support the theory that L1 can facilitate the learning of L2 and to demonstrate that the use of L1 does not impede learning. The result of these studies indicated that L1 use is accepted by most students and supported by teachers. Teachers supported the functional use of L1 and the use of L1 promoted the classroom interaction.

The learners' mastery on native language rules function as the resource of communication, at least for temporary use. This strategy is perhaps better than avoid speaking because of limitation of target language mastery. For this reason, Corder (1981) argues that the L2 learner's language will be mixed or intermediate system between the target language and other languages, most possibly his native language.

The use of native language in the classroom settings can be an aid to language learning (Kavaliauskiene, et all, 2010). In general, learners keep mentally translating from L1 to L2 and 
vice versa. This situation makes foreign language teachers aware of the important of translation in English classroom.

Inbar-Lourie (2010) investigated that teachers generally employ learners' native language for the three main purposes namely instructional i.e., facilitating comprehension, explaining grammar, new lexical items and concepts, classroom management, providing feedback, and for affective purposes, particularly encouraging and providing comfort for learners. In addition, Littlewood \& Yu (2011) assumed that L2 teachers use learners' L1 mainly to establish constructive social relationships, clarify complex meanings, save time in class, exert control over the classroom, and ensure understanding. A research conducted by Storch and Aldosari (2010) showed that participating learners employed L1 mainly for task management and discussing about vocabulary. They also concluded that L1 may serve important cognitive, social, and pedagogical function and restricting or prohibiting the use of learners' L1 is to turn a blind eye to an effective tool (Mohebbi\&Alavi, 2014).

With the implementation of foreign language teaching objective in order to achieve communication skills, there is probably a question can be raised. The question is: how can non English department students communicate in the target language before they have mastered the system of the target language? This question is merely for teachers who teach English to nonEnglish department students. There are two possible answers for the question. First, possibly the learners will avoid speaking since they cannot express their ideas because limitation of their mastery on the target language. If this happens, there should be some ways which help the learners prepare to communicate. In this case, the explanation of grammar rules prior to the speaking activities is possibly important. This is because naturally a language has a set of rules and the use of the language cannot be separated from its rules.The second possibility is that the learners will make up their own strategies to cope with their communication and most possibly they will use their native language. They will use their native language rules using the target language vocabulary.

\section{RESEARCH METHOD}

This research wanted to describe the reasons of native language use as medium of instruction at non English department. Type of research used in this research was descriptive quantitative research by survey model. Stephen and William (1982) said that surveys are the most used technique in education; they are means of gathering information to asses need and set goals. 
The population of this research was non English Department students and English teachers of Faculty of Culture, Management and Business in Undikma University of Education.The students as the survey group in this research were to figure out some reasons of native language as medium of instruction at non English department. For this purposethere were 14 studentsand two general English lecturerswere taken as samples.

Questionnaires were the instrument of the research. The questionnaires distributed to both students and lecturers. Each data as the result of questionnaires were calculated infrequencies and percentage.

\section{FINDINGS AND DISCUSSION}

Students' answers to the questionnaires are analyzed in frequency and percentage. The table below is the reason of using Indonesian as medium of instruction.

Table 1. The reason of using Indonesian as medium of instruction

\begin{tabular}{|l|l|c|c|}
\hline Number & Reason & Frequency & Percentage \\
\hline 1 & $\begin{array}{l}\text { To explain new English teaching material in students' } \\
\text { native language }\end{array}$ & 8 & 50 \\
\hline 2 & $\begin{array}{l}\text { To explain difficult words in reading text in students' } \\
\text { native language }\end{array}$ & 10 & 62.5 \\
\hline 3 & To explain grammar & 5 & 31.25 \\
\hline 4 & Using Indonesian makes English easy to learn & 10 & 62.5 \\
\hline 5 & To develop learning atmosphere more comfortable & 7 & 43.75 \\
\hline 6 & $\begin{array}{l}\text { To develop students' understanding in reading } \\
\text { comprehension }\end{array}$ & 9 & 56.25 \\
\hline 7 & To ensure understanding of previous teaching material & 8 & 50 \\
\hline 8 & To explain error made by the students & 11 & 68.75 \\
\hline 9 & Giving instruction for assignment or test & 7 & 43.75 \\
\hline 10 & Discuss among students is easier & 9 & 56.25 \\
\hline
\end{tabular}

The teachers and the students used Indonesian for some reasons in different occasions or aspects of teaching. Based on the data, the using of Indonesia can be applied in 1). Teaching English skills;2). Components of the language skills, and 3). Class management. For teaching English skills, the reasons of using Indonesia are: To develop students' understanding in reading comprehension (56.25\%), discuss among students is easier (56.25\%), and using Indonesian makes English easy to learn (62.5\%). The using of Indonesian in component of language skills can be seen in the activity to explain difficult words in reading text in students' native language (62.5\%), to explain grammar (31.25\%), to explain error made by the students $(68.75 \%)$. The using of Indonesian in classroom management can be seen in explaining new English teaching material in students' native language (50\%), to develop learning atmosphere is more 
comfortable (43.75\%), to ensure understanding of previous teaching material (50\%) and giving instruction for assignment or test (43.75\%).

\section{CONCLUSION}

Based on the result of classroom observation and interview toward both English teachers and non-English Department students some conclusions can be drawn. The use of Indonesian in English class gave positive effect for both students and teachers. It can overcome several problems of teaching and learning English for non-English department students. However, the portion of using Indonesian by the teachers and the students are different; teachers used English more often than Indonesian but students use English limitedly.

There were ten reasons of using Indonesian as medium of instruction for non-English department students. Those ten reasons covered three functions for teaching that covered teaching language skills, teaching the component of language, and class management. For teaching language skills aimed to develop students' understanding in reading comprehension, to discuss among students is easier, and to make English easy to learn. The using of Indonesian in component of language skills aimed to explain difficult words in reading text in students' native language, to explain grammar, to explain error made by the students. The reasons of using Indonesian in classroom management are to explain new English teaching material in students' native language, to develop learning atmosphere more comfortable, to ensure understanding of previous teaching material and giving instruction for assignment or test.

\section{REFERENCES}

Ahmad, I., Radzuan, N. R. M., \& Hussain, M. S. (2018). Use of First Language in the Classroom: Non-native EFL Teachers' Belief in Teaching English to Adult Learners in Bilingual Context. Arab World English Journal (AWEJ), 9(2), 186-199.

Atkinson, D. (1987). The mother tongue in the classroom: A neglected resource? ELT Journal. https://doi.org/10.1093/elt/41.4.241

Atkinson, David, 1993. Teaching Monolingual Classes. London: Longman

Christina V. (2012). Overusing mother tongue in English Language teaching. International Journal of Communicative Research, 2(3), 212-218retrieved fromhttps://www.ijcr.eu/articole/84 30 IJCR\%203-2012.pdf on May 20,2020

Ellis, Rod. (1985). Understanding Second Language Acquisition. New York: OUP

Inbar-Lourie, O. (2010). English only? the linguistic choices of teachers of young EFL learners. International Journal of Bilingualism, 14(3), 351-367. https://doi.org/10.1177/1367006910367849 
Joukoulian, Anny. 2016. Teaching English as a Foreign Language Today Integrated Approach versus Communicative Approach.CALR linguistics Journal Center For Applied Linguistics Research Arab Open University Lebanon Issue 7 Revisiting The Communicative Approach December 2016http://web.aou.edu.lb/online-journals/issue-7

Kavaliauskiene, Galina., Mezeikiene, Viktorija\&Valunaite-Oleskeviciene, Giedre. (2010). Role of Native Language in Learning English. Santalka.FilologijaEdukologija 2010 18(2). 35-42. $\quad$ doi: $10.3846 /$ coactivity.2010.12 https://www.researchgate.net/publication/240822325 Role of Native Language in Le arning_English

Krashen, Stephen D. (1982). Principle and Practice of Second Language Acquisition. Oxford: Permagon

Littlewood, W., \& Yu, B. (2011). First language and target language in the foreign language classroom. Language Teaching. https://doi.org/10.1017/S0261444809990310

Madrinan, Mara Salmona. 2014. The Use of First language in the Second Language Classroom: A Support for Second Language Acquisition. Gist Education and Learning Research Journal, No. 9. (July-December) 2015, 50-66 retrieved from https://eric.ed.gov/?id=EJ1062663 on May 12, 2020

Mohebbi, Hassan.,\&Alavi Mohammad. 2014. An Investigation into Teachers' First Language Use in a Second language Learning Classroom Context: A Questionnaire-based Study. Bellaterra Journal of Teaching and learning Language \& Literature, 7(4), 57-73

Ostovar, Seyyed Ali, Norouzi Shabnam, Namaghi. 2015. First language Use In teaching A Foreign Language: Theoretical Perspectives and Empirical Findings. US-China Foreign Language, September 2015, Vol. 13 No. 9, 615-622

Prodromou L. (2002). From Mother Tongue to Other Tongue. Retrieved from https://www.teachingenglish.org.uk/article/mother-tongue-other-tongue on May 18, 2020

Rodriguez Juarez, Carolina.,\&Oxbrow,Gina (2008). L1 in the EFL Classroom: More a Help than a Hindrance? Porta Linguarum, 9, 93-109.Retrieved from https://digibug.ugr.es/handle/10481/31748 On May 20,2020

Storch, N.,\&Aldosari, A. (2010). Learners' Use of First Language (Arabic) in Pair Work in EFL Class. Language Teaching Research. 14 (4), 355-375.

Swain, M. (2008). The Output Hypothesis: Its History and Its Future. Foreign language Teaching and Research. 40(1), 45-50.Retrieved from http://www.celea.org.cn/2007/keynote/ppt/Merrill\%20Swain.pdf on May 20,2020 